\title{
EDUCOMUNICAÇÃO PARA A GESTÃO DAS ÁGUAS: ESTUDO DE CASO DO CURSO ELABORAÇÃO DE SPOTS E MANUSEIO DA PLATAFORMA WEB RÁDIO ÁGUA
}

\author{
Mônica Alves ${ }^{1}$ \\ Jan Alyne Barbosa Prado ${ }^{2}$ \\ Alberto Fonseca ${ }^{3}$
}

Resumo: Este estudo buscou entender como a educomunicação pode contribuir para o fortalecimento comunicativo da gestão das águas. Mais especificamente, buscou-se avaliar como as áreas de intervenção educomunicativas foram incorporadas no curso Elaboração de Spots e Manuseio da Plataforma Web Rádio Água, ministrado para os gestores do Comitê de Bacia Hidrográfica do Rio Paranaíba. A metodologia seguiu uma abordagem qualitativa de estudo de caso único, com dados coletados através da observação direta, de entrevistas semiestruturadas e análises documentais. Uma das conclusões da pesquisa aponta que, embora o curso siga conceitos educomunicativos, o resultado não foi alcançado em sua totalidade, sobretudo devido a equívocos na sua gestão comunicativa.

Palavras-Chave: Educação Ambiental; Sustentabilidade; Diálogo de Saberes. 


\section{Introdução}

A Lei no 9.433/97, conhecida como Lei das Águas criou um novo paradigma para gestão dos recursos hídricos no Brasil, com a garantia da participação da sociedade civil e dos usuários, junto ao Poder Público, em um modelo de governança compartilhada e democrática. Mas, até a sua instituição legal, várias ações contribuíram para normatização desse novo modelo de gestão. A começar pelos movimentos sociais das décadas de 1960 e 1970, que se espalharam pelos países latino-americanos em contraposição à forma de Governo vigente, cuja participação popular era insignificante. A promulgação da Constituição Federal no ano de 1988 colaborou também nesse sentido, ao mudar o atributo das águas de todo territorial nacional de particular para pública, em qualquer tipo de atividade.

A Política Nacional de Recursos Hídricos (PNRH), prevista na Lei das Águas, pautou-se nos termos "descentralizado, colegiado, integrado e participativo" para sistematizar este novo modelo de governança hídrica. Por meio do Sistema Nacional de Gerenciamento de Recursos Hídricos (SINGREH) foram instituídas as diretrizes para criação dos comitês de bacias hidrográficas (também chamados de Parlamento das Águas), que seriam os órgãos colegiados responsáveis por esta gestão.

Nesse formato, os representantes da sociedade civil e dos usuários conquistaram, além do direito de participação, a função deliberativa, ou seja, o poder de definir regras, estabelecer formas para a sua aplicação, acompanhar o desenvolvimento dos processos e ainda intermediar acordos em casos de conflitos. A adoção da bacia hidrográfica como recorte territorial também foi considerada um avanço "por estender as barreiras políticas e tradicionais (municípios, estados e países) para uma unidade física de gerenciamento, planejamento econômico e social' (TUNDISI, 2013, p.230).

O Brasil contava em 2017 com mais de 200 comitês de bacias hidrográficas, em diferentes etapas de implantação, de acordo com a Agência Nacional de Águas (BRASIL, 2016). Esses números sugerem, de forma quantitativa, que os comitês de bacias estão se estabelecendo no país; no entanto, não validam que este modelo de gestão esteja funcionando na prática, conforme previsto nos parâmetros legais.

Estudiosos sobre esta temática apontam que, nos processos de consolidação, os $\mathrm{CBHs}$ se esbarram no confronto de interesses sobre os múltiplos usos da água nos aspectos sociais, econômicos, culturais, históricos e políticos. E que estes fatores somados à prevalência do discurso técnico, comprometem a proposta da gestão compartilhada, participativa e democrática. Taddei (2011), em seu artigo Social Participation in Water Management in Northeast Brazil4, problematiza essa questão, ao afirmar que o discurso técnico dificulta e desestimula a participação dos representantes da sociedade civil,

4 Democratização diluída: modernização versus participação social na gestão da Água no Nordeste do Brasil (TADDEI,2011, tradução própria)

Revbea, São Paulo, V. 12, № 5: 200-217 2017.

revista brasileira educação ambiental 
que não estão familiarizados com este tipo de linguagem. Para Jacobi (2006, p. 225), o grande problema "é que a capacidade de negociação e de estabelecer pactos se balizam pelos limites da prevalência do componente técnico como referencial de controle do processo".

Dentre as possibilidades em pensar o fortalecimento da articulação comunicativa dos diversos atores que compõem a gestão das águas, optou-se em percorrer o caminho da educomunicação. Um campo ainda recente, comparado a tantas outras abordagens teórico-metodológicas da comunicação e de outras áreas, no entanto, atual e pertinente por ajudar a dirimir as assimetrias da retórica entre os atores envolvidos em um processo de tomada de decisões.

O objetivo deste estudo foi entender como os princípios da educomunicação foram implementados no curso Elaboração de Spots e Manuseio da Plataforma Web Rádio Água, aplicado pelo Projeto Web Rádio Água, no Comitê de Bacia Hidrográfica do Rio Paranaíba (CBH-Paranaíba), por meio de uma parceria entre a Fundação Parque Tecnológico de Itaipu (FTPI) e Agência Nacional de Águas (CONVÊNIO № 001/ANA/2011). Mais especificamente, o estudo analisou: 1) o conteúdo do curso disponível no Manual Web Rádio Água no sentido de diagnosticar em quais áreas de intervenção educomunicativa ele transitou; 2) como os participantes aplicaram as práticas educomunicativas na elaboração do produto midiático proposto no curso (spot); e, 3) como a educomunicação foi incorporada em um curso na modalidade de educação a distância.

\section{O caso "Elaboração de Spots e Manuseio da Plataforma Web Rádio Água"}

A análise do curso Elaboração de Spots e Manuseio da Plataforma Web Rádio Água justifica-se pela singularidade da sua proposta de formar comunicadores comunitários. O foco do curso é a capacitação para produção de spots, que "são comerciais publicitários veiculados no rádio, que geralmente transmitem mensagens especialmente elaboradas com intenção de vender ideias, produtos, bens e serviços" (SILVA, 1999, p. 30). Na proposta da Web Rádio Água, os spots têm o caráter de prestação de serviço público no sentido de despertar e estimular o público para mudanças de concepções e comportamentos para o uso sustentável dos recursos hídricos (MANUAL WRA, 2012). A opção pelo curso fundamenta-se também na iniciativa precursora do projeto de disponibilizar um meio eletrônico, a Plataforma Web Rádio Água, para postagem dos produtos educomunicativos (spots), instituindo um espaço colaborativo que possibilita o intercâmbio de informações sobre a temática hídrica.

Na modalidade semipresencial de Educação a Distância (EAD), o curso tem uma carga horária de 38 horas, sendo que 22 horas correspondem aos estudos on-line e as demais direcionadas para as oficinas presenciais. A comunicação educativa é a linha pedagógica norteadora do curso, dentro da proposta da criação de espaços dialógicos para a construção coletiva e para o processo de aprendizagem que se fundamenta na relação entre as pessoas, que são estimuladas a desenvolver as habilidades comunicacionais em ações 
de troca de conhecimentos. $\mathrm{O}$ jornalismo de desenvolvimento ${ }^{5}$ complementa a proposta pedagógica do curso na abordagem e condução das notícias, de forma que suas pautas busquem ações com resultados positivos a serem compartilhados com a coletividade. O curso preconiza a difusão de boas práticas com a proposta de mobilizar a comunidade, permitindo a ela 0 conhecimento "de experiências bem sucedidas para a gestão dos recursos hídricos" (MANUAL WRA, 2012, p.17).

Integrando à comunicação educativa e ao jornalismo de desenvolvimento, o curso aplica o conceito da mediação pedagógica na concepção teórica de Paulo Freire (1987), de que o conhecimento é construído com base nos processos de reflexão crítica e de ações práticas. Desta forma, a comunicação se materializa na oportunidade dada para que todos se expressem durante o processo de criação conjunta, cujo produto final (spot) seja o resultado do intercâmbio desses diversos saberes e da vivência de colocá-los em prática.

O Comitê de Bacia Hidrográfica do Rio Paranaíba foi o primeiro a ser instituído no Brasil, em 2 de maio de 2012. Com sede em Ituiutaba (GO), as atividades do $\mathrm{CBH}$-Paranaíba se iniciaram em 18 de setembro de 2008, para fazer a gestão da água de toda bacia hidrográfica do rio de mesmo nome, que nasce na Serra do Mato da Corda e percorre cerca de $1.160 \mathrm{~km}$ até a sua foz, no encontro com o rio Grande em Minas Gerais (CBH-Paranaíba, on-line). Este território abrange 197 municípios, que juntos somam uma população aproximada de 9 milhões de habitantes. É a maior unidade hidrográfica do Rio Paraná, com $25,4 \%$ de sua área, incorporando parte dos estados de Goiás $(65 \%)$, Minas Gerais (30\%), Distrito Federal (3\%) e do Mato Grosso do Sul $(2 \%)$.

O curso foi disponibilizado para os gestores do $\mathrm{CBH}$-Paranaíba em sua etapa on-line no período de 16 de julho a 10 de agosto de 2012. Nos dias 14 e 15 de agosto do mesmo ano, os cursistas se reuniram na cidade de Goiânia (GO) para participarem das oficinas de produção de spots, entrevistas radiofônicas e manuseio da Plataforma Web Rádio Água. A Agência Nacional de Águas cedeu para o CBH-Paranaíba um kit de gravação, composto por: computador, microfone, caixas de som, mesa de som, gravador e máquina fotográfica, para serem usados nas aulas presenciais e nas ações a serem desenvolvidas pós-curso.

${ }^{5} \mathrm{O}$ jornalismo de desenvolvimento apareceu pela primeira vez nos meados de 1967, para definir uma visão de jornalismo, segundo a qual a reportagem dos eventos de importância nacional e intencional deveria ser construtiva, no sentido de contribuir positivamente para o desenvolvimento do país em questão (KUNCZIK, 2002, p.131).

revista brasileira educação ambiental 


\section{Metodologia}

Ao observar a diversidade de métodos de análise que poderiam dar sustentação ao objetivo principal desse trabalho, optou-se pelo estudo de caso, em uma abordagem qualitativa (YIN, 2001, p.29). No processo metodológico, soma-se a participação de um dos autores deste artigo na etapa on-line do curso, que permitiu uma observação direta intensiva, que utiliza os sentidos na obtenção de determinados aspectos da realidade. "Não consiste apenas em ver e ouvir, mas também examinar fatos ou fenômenos que se deseja estudar" (LAKATOS; MARCONI, 1992, p. 107). A aplicação desse método permitiu a este autor conhecer com profundidade como o curso foi formatado na plataforma on-line e como se procediam as mediações entre participantes e tutores.

Para complementar os dados levantados com a observação direta e a análise do conteúdo do material do curso, utilizou-se também da técnica de entrevista, que é um recurso metodológico para melhor compreensão do objeto estudado e/ou para certificação de dados. Optou-se pela entrevista na tipologia semiestruturada, na qual seguiu um roteiro-base, com flexibilidade para complementação dos dados a partir do momento que surgiam novas dúvidas. Foram realizadas entrevistas com atores que tinham relação direta com 0 projeto Web Rádio Água/Curso, CBH Paranaíba e a Agência Nacional de Águas.

Para análise da aplicação das práticas educomunicativas no curso Elaboração de Spots e Manuseio da Plataforma Web Rádio Água adotou-se como critérios as "áreas de intervenção", que segundo Soares (2011), são as portas de ingresso às práticas educomunicativas. São elas: Educação para a comunicação; Pedagogia da comunicação; Expressão pela arte; Produção midiática; Mediação tecnológica na educação; Epistemologia da educomunicação; e Gestão da comunicação. Essas áreas de intervenção são explicadas no próximo tópico.

Durante o estudo, procurou-se levantar os pontos assertivos e as fragilidades e pensar propostas de ações, dentro dos conceitos da interface educação e comunicação, que poderiam agregar ao curso. Devido à quantidade de material coletado, optou-se por apresentar as análises não de forma segmentada, seguindo o processo de coleta de dados, ou seja: observação direta, análise do material e entrevistas. Por isso, em determinados momentos se apresentam trechos do material, em outros, relatos da observação direta e, em algumas partes, as entrevistas realizadas. Como este estudo assume um compromisso de sigilo e confiabilidade e, para tanto, sempre que mencionadas as fontes, elas não terão seus nomes revelados. Optou-se pela identificação numérica: Entrevistado 1, Entrevistado 2, Entrevistado 3, Entrevistado 4, Entrevistado 5. As análises serão apresentadas por área de intervenção. 


\section{Sobre a educomunicação}

A educomunicação, conforme definiu Soares (2006), é muito mais que a junção dos campos da comunicação e educação. Na realidade, além de unir as duas áreas, destaca-se de modo significativo um terceiro termo, a ação:

É sobre o termo ação que continua a recair a tônica quando a palavra é pronunciada, dando-Ihe assim, ao que parece, um significado particularmente importante. Educação e/ou comunicação - assim como na educomunicação - são formas de conhecimentos, áreas do saber ou campo de construções que têm na ação seu elemento inaugural (SOARES, 2006, ONLINE).

A criação no ano de 1996 do Núcleo de Comunicação e Educação (NCE) no espaço da Universidade de São Paulo (USP), que reuniu um grupo de professores de várias universidades brasileiras interessado em pesquisar sobre a inter-relação comunicação e educação, foi o marco institucional para o campo da educomunicação. A primeira ação do NCE/USP foi "uma pesquisa junto a especialistas de 12 países da América Latina e da Península lbérica para saber o que pensavam os coordenadores de projetos na área e qual o perfil dos profissionais que trabalhavam nesta inter-relação" (NCE, on-line). A codificação do resultado desta pesquisa, conforme descrito no site do próprio núcleo, culminou na definição da educomunicação, como sendo:

O espaço em que membros da sociedade se encontram para implementar ecossistemas comunicativos democráticos, abertos e participativos, impregnados da intencionalidade educativa e voltados para a implementação dos direitos humanos, especialmente o direito à comunicação ( NCA, online).

Antevendo a estes fatos citados anteriormente, já nas décadas de 1960 e 1970, Paulo Freire e Mário Kaplún "vislumbravam na junção educação e comunicação, a possibilidade de promover nas massas a consciência crítica que leva à transformação" (LIMA, 2009, p.39). Para Freire (2003, p.67), o que os meios de comunicação de massa fazem "é comunicado, é transferência de dados, de forma ideológica e antidialógica e em nada contribuem para a emancipação dos sujeitos. Pelo contrário, favorecem a opressão, a manipulação e a perda da identidade cultural". Kaplún (1987) reforçou essa linha de pensamento ao criticar o processo no qual um emissor produz e repassa a informação para milhares de receptores e ao defender que todo ser humano é dotado de capacidades para os papéis de emissor e receptor. Para Kaplún (2014, p.67), a cidadania se fortalece a partir do momento que o conhecimento caminha com "a observação pessoal, a confrontação e o 
intercâmbio, o cortejo de alternativas, o raciocínio crítico e a elaboração criativa". Quanto mais os sujeitos forem potencializados como emissores de seus próprios saberes, mais terão domínio de si e das situações que o rodeiam.

Freire e Kaplún se convergem também ao considerarem que é possível construir outro tipo de relação entre e com os agentes da comunicação e da educação, sem atores passivos, mas sim sujeitos dialógicos. Um modelo baseado na participação ativa e interativa. $O$ conceito de educomunicação defendido pelo Núcleo de Comunicação e Educação da USP, segue este mesmo pressuposto, "que a educação só é possível, enquanto ação comunicativa" (SOARES, 2011, p.1), cujo princípio está nas práticas democráticas e participativas. Ao protagonizarem a produção e difusão da informação, os atores se familiarizam com o mundo midiático e, nesse processo, além de desenvolverem o poder expressivo, despertam para uma visão mais crítica dos meios.

Valendo-se da proposta desse artigo de apresentar as análises de um curso construído dentro dos parâmetros educomunicativos, mas aplicado na modalidade semipresencial de educação a distância, é importante discorrer sobre como a educomunicação transita no modelo EAD. A complexidade dos cursos on-line, concebidos nos parâmetros educomunicativos, está na formação dos ecossistemas comunicativos - que são os espaços onde o diálogo se estabelece, onde aconteceriam, como propôs Freire (2006, p.69) "os encontros de sujeitos interlocutores que buscam a significação dos significados". Para Soares (2002), a problematização está no tipo de solução que está sendo proposta para que a intercomunicação não seja comprometida pela sua aplicação na modalidade a distância. "O foco é como estão se integrando as pessoas que produzem o conteúdo, que fazem a mediação e as que recebem este conhecimento" (SOARES, 2002, p.71).

Os pesquisadores do NCA/USP desenvolveram e aplicaram o primeiro curso na modalidade semipresencial de educação a distância na perspectiva educomunicativa, no ano de 2002. A iniciativa envolveu mais de 2.250 educadores vinculados a escolas públicas do estado de São Paulo durante um período de sete meses. O resultado do curso denominado 'Linguagem Audiovisual na Escola - uma Ação Educomunicativa', ou, simplesmente, Educom.TV, que foi sistematizado em artigos publicados em periódicos científicos, apresentou um indicador positivo: o baixo índice de desistência. "Do total de inscritos, $89 \%$ se mantiveram até o final do curso. Pela literatura existente, a média internacional de fidelidade e permanência para cursos via Internet com essa duração é de no máximo, 30\% dos inscritos" (SOARES, 2002, p.58).

O baixo índice de evasão é relacionado, por Soares (2002), aos fluxos comunicativos estimulados durante os encontros presenciais: 
Todos os 2.240 cursistas tiveram a oportunidade de participar de um momento presencial quando puderam dialogar com colegas, os representantes da Secretaria de Educação e a equipe do NCE-ECA-USP. Os seminários, com duração de 32 horas, realizados sempre em Águas de Lindóia, foram marcados pela surpresa do encontro entre os cursistas e seus respectivos tutores, em geral mais novos, mas suficientemente embasados para a tarefa que exerciam, levando em conta que predominavam entre eles mestrandos e doutorandos da ECA. Questões teóricas e metodológicas foram abordadas. (SOARES, 2002, p. 68).

De acordo com o autor (lbid), após a realização dos encontros presenciais, onde prevaleceram as discussões sobre os conceitos do campo da educomunicação, as trocas on-line foram potencializadas. Outro ponto positivo citado por Soares (2011) foi a construção coletiva do curso, envolvendo os gestores, produtores, tutores e a equipe técnica:

Fizemos uma construção compartilhada dos conteúdos, com a distribuição das tarefas de produção dos conteúdos. Cada um dos dez tópicos foi elaborado por um grupo de trabalho constituído por um dos professores orientadores e um grupo de tutores. Uma vez elaborados, os conteúdos de cada tópico eram submetidos à apreciação de toda equipe dos 35 tutores, bem como a equipe operacional, nas reuniões semanais [...]. Desde o início, ficou estabelecido que a plataforma web seria construída em conjunto pelos produtores dos conteúdos e pelos projetistas do sistema de suporte (SOARES, 2011, p.21).

O envolvimento do educomunicador/tutor na concepção e elaboração do curso favorece o desempenho do seu papel de mediador nas práticas educomunicativas. Para Soares $(2002,2011)$, cabe ao educomunicador/tutor:

[...] as funções de promover ações inclusivas (todos os atores devem se sentir envolvidos ao processo), democratizá-las (fazer prevalecer a igualdade) e midiatizá-las (fomentar o fazer coletivo na utilização dos recursos tecnológicos) de forma criativa (reconhecer e valorizar as culturas locais) (SOARES, 2002, p. 25; 2011, p.45).

Conforme explicado no tópico onde foi descrita a metodologia da pesquisa, para análise da aplicação das práticas educomunicativas no curso Elaboração de Spots e Manuseio da Plataforma Web Rádio Água adotou-se como parâmetros as áreas de intervenção. Divididas em sete campos, essas 
áreas serão descritas a seguir, com base nas definições propostas pelo Núcleo de Comunicação e Educação (NCE) da Universidade de São Paulo (USP):

Educação para a comunicação - Nesta linha de intervenção, o objetivo é dialogar sobre o papel dos meios e os seus processos produtivos e ideológicos, com a finalidade de "levar os envolvidos a entender a importância da comunicação para utilizá-la eficazmente" (ALMEIDA, 2016, p.24). Além da linguagem e produção midiáticas, trabalha com técnicas para tornar a comunicação interpessoal eficiente e para despertar nos sujeitos a análise crítica sobre o papel hegemônico dos meios de comunicação convencionais e seu poder manipulativo. O caminho está na produção midiática conjunta, que permitirá os atores sociais transitarem pelos papéis de produtor emissor e receptor da mensagem.

Pedagogia da comunicação - Esta área se fundamenta na comunicação pela perspectiva dialógica, proposta por Paulo Freire (1969), na qual os conteúdos não são depositados, mas interlocutados. "Um bom pedagogo da comunicação expõe diversos pontos de vista sobre os assuntos, oferece subsídios para que os sujeitos comparem argumentos contraditórios, reflitam e tirem suas próprias conclusões" (ALMEIDA, 2016, p.26).

Expressão pela arte - A orientação para esta intervenção é promover a interação por meio da linguagem artística, no sentido de contribuir para o desenvolvimento comunicativo dos atores que têm limitações na expressão oral. Nessa área, as tecnologias de comunicação e informação são importantes ferramentas para trabalhar a inclusão. Com a utilização dessas tecnologias, os esforços de arte-educadores se movem no sentido de garantir espaços de fala, visibilidade e livre expressão para cada um dos sujeitos sociais em situações de vulnerabilidade por meio de "práticas que valorizam a autonomia comunicativa mediante a expressão artística - arte-educação" (SOARES apud ALMEIDA, 2016, p.138).

Produção midiática - Neste campo de intervenção, a produção midiática tem o viés educativo, que pode ser aplicado por meio da produção de jogos, filmes, spots, novelas, jornais, revistas, fanzines, blogs, páginas nas redes sociais, e-book, sites, entre outros. Sua área de atuação são os ambientes de educação formais ou não formais, seguindo o princípio básico da produção coletiva e dialógica e tendo como principal objetivo a elaboração de um produto midiático com fins educativos, respeitando e valorizando a cultura local.

Mediação tecnológica na educação - A proposta desta área de intervenção é a utilização das tecnologias da comunicação e informação nos processos educativos. "Preocupa-se com a presença das tecnologias como elemento interveniente nas mediações culturais que mobilizam a sociedade, com influências nos modos de perceber o mundo e de produzir cultura" (SOARES, 2014, p.12 apud ALMEIDA, 2016, p.26). Neste propósito, os ambientes virtuais devem ser trabalhados para potencializar as relações e 
produções coletivas, oportunizando-se da facilidade de interações instantâneas de atores de diversos territórios.

Epistemologia da educomunicação - A pesquisa científica é a fundamentação desta área de intervenção que tem como o foco a proposta de certificar, mensurar e avaliar o campo da educomunicação. Como definiu Soares (2014, p.140), buscar através da análise "a constituição, os fundamentos teóricos, as metodologias e os espaços de trabalho da educomunicação". Tem na universidade seu principal campo de atuação, podendo abranger o tripé - ensino, pesquisa e extensão.

Gestão da comunicação - A principal proposta interventiva desta área é a coordenação dos ecossistemas comunicativos, desde a sua implantação, passando pela manutenção, monitoramento e avaliação. Esta gestão tem início desde a concepção do projeto, com a elaboração do diagnóstico e do planejamento das atividades e deve privar pela construção participativa, interativa, democrática e dialógica. Trata-se de um campo estratégico, por isso o gestor deve conhecer toda a logística do processo e atuar para que a engrenagem funcione da melhor forma possível.

A partir do momento que estas áreas foram sistematizadas é possível utilizá-las como parâmetros no sentido de analisar quais as diretrizes educomunicativas estão sendo adotadas, relacionando-as às propostas a serem alcançadas. E este foi o caminho seguido pelo estudo proposto para este artigo.

\section{Análise dos resultados}

Durante o estudo, procurou-se levantar os pontos assertivos e as fragilidades da concepção educomunicativa aplicada no curso e pensar propostas de ações, dentro dos conceitos da interface educação e comunicação, que poderiam agregar ao projeto. Devido à quantidade de material coletado, optou-se por apresentar as análises não de forma segmentada, seguindo o processo de coleta de dados, ou seja: observação direta, análise do material e entrevistas. Por isso, em determinados momentos se apresentam trechos do material, em outros, relatos da observação direta e, em algumas partes, as entrevistas realizadas. Como este estudo assume um compromisso de sigilo e confiabilidade e, para tanto, sempre que mencionadas as fontes, elas não terão seus nomes revelados. Optou-se pela identificação numérica: Entrevistado 1, Entrevistado 2, Entrevistado 3, Entrevistado 4, Entrevistado 5. As análises serão apresentadas por área de intervenção educomunicativa. Dos sete campos, as áreas da Expressão pela arte e da Epistemologia da educomunicação não foram enquadradas nas análises, pela não adequação das mesmas com os objetivos do curso.

Os resultados apresentados a seguir alicerçaram-se nos pressupostos teóricos descritos no corpo desse artigo, com base na compreensão dos autores.

revista brasileira educação ambiental 


\section{Educação para a comunicação}

Ao propor a compreensão das técnicas para elaboração de uma entrevista radiofônica, dos métodos que norteiam a entrevista radiofônica e a captação e edição de áudios (spots), o curso abre espaço para o conhecimento dos fundamentos teóricos e práticos do processo da produção midiática. Possibilita também aos cursistas, a familiarização com a linguagem midiática e com os procedimentos tecnológicos necessários para 0 manuseio da Plataforma WRA.

Durante as aulas presenciais, foram elaboradas três produções midiáticas. O primeiro $\operatorname{spot}^{6}$ (de um minuto e cinco segundos) foi uma campanha informativa sobre os perigos das queimadas, tanto para a flora e a fauna, como para a vida humana. Foram utilizadas quatro vozes, além de efeitos sonoros e trilha musical. O spot foi postado na Web Rádio Água no dia 15 de agosto de 2012, no último dia de curso presencial, pela própria equipe da plataforma. $\mathrm{O}$ spot $^{7}$ de número 2, com 55 segundos, abordou o turismo sustentável no Lago Bom Sucesso, utilizando uma voz masculina e outra feminina. A postagem foi feita no dia 2 de setembro de 2012, pela equipe da WRA. O terceiro spot $^{8}$ foi uma campanha educativa que alerta para o uso indiscriminado da água. Duas vozes femininas simulam um diálogo entre vizinhas. Esta foi a primeira postagem feita pelos próprios integrantes do $\mathrm{CBH}$, datada de 12 de setembro de 2012.

Nessas três produções, observa-se claramente o envolvimento dos atores participantes do curso na produção midiática, ou seja, adotaram-se conceitos do campo educomunicativo "ao privilegiar o processo diante do produto e garantir o acesso, a participação e a apropriação do caminhar de parte dos agentes implicados" (SOARES, 2014, p.156). No processo de elaboração dos spots, os cursistas tiveram a oportunidade de desenvolver suas habilidades expressivas e conhecerem como a manipulação pode estar embutida nas produções midiáticas.

\section{Pedagogia da comunicação}

O conteúdo pedagógico do curso se enquadra nesta área de intervenção a partir do momento que segue as diretrizes da comunicação educativa, "que procura promover o acesso de cidadãos comuns ao processo de produção e difusão de conteúdos, fazendo com que, a partir daí, haja intercâmbio de conhecimento, desenvolvimento social e construção da cidadania" (MANUAL

6 O spot pode ser ouvido no link: http://migre.me/w5LOo, acessado em 10 de janeiro de 2017.

$7 \quad$ Este spot pode ser acessado no link: http://migre.me/w5N7I. A pesquisadora deve acesso ao áudio no dia 15 de janeiro de 2017.

$8 \quad O$ áudio do spot pode ser acessado no link: http://migre.me/w5Mj6. O acesso da pesquisadora foi em 15 de janeiro de 2017.

Revbea, São Paulo, V. 12, № 5: 200-217, 2017. 
WEB RÁDIO, 2012, p.7). A proposta pedagógica promove a interlocução entre os cursistas no processo de construção coletiva, ao adotar a teoria freiriana "de que os sujeitos constroem o conhecimento um com o outro, mediatizados pelo mundo" (FREIRE, 1987, apud MANUAL WEB RÁDIO, 2012, p. 21). O curso opta pela coprodução, onde os cursistas são seus próprios mediadores, ou seja, "construtores do conhecimento individual e coletivo, seja na dimensão biológica, física, cultural, social ou planetária" (MANUAL WEB RÁDIO, 2012, p.7). Por meio dos conteúdos oferecidos, trabalha-se a interação para a troca de experiências e, nesse processo de construção embasada no intercâmbio de ideias, objetiva-se a transformação dos modos de ser e agir dos cursistas na sua relação de envolvimento com as causas hídricas.

O curso incorpora os preceitos da área de intervenção da pedagogia da comunicação, pois trabalha as ações comunicativas de formas interpessoal e intrapessoal entre os cursistas, com foco no desenvolvimento da expressividade, do saber ouvir, do saber explicitar contradições, problematizar temáticas e provocar reflexões, entre outros saberes.

Desta forma, as ações coletivas não ficam restritas somente ao produto final. Elas se estendem para as reflexões que levam os cursistas a se perceberem como agentes de mudança. Esse processo é potencializado nos encontros presenciais, pela possibilidade de maior interação entre os cursistas. No entanto, um único momento presencial, no final do curso, compromete o fluxo comunicacional, mesmo que ele seja favorecido nas atividades on-line. Compromete-se ainda mais por ter sido realizado no final do curso. Um contato presencial no início do curso potencializaria o processo comunicativo on-line, à posteriori.

\section{Produção midiática}

A produção midiática tem um campo extenso que pode ser explorado, que vai desde o filme a jogos eletrônicos. Uma das ferramentas midiáticas utilizada no curso Elaboração de Spots e Manuseio da Plataforma Web Rádio Água foi o vídeo. Os conteudistas apropriam desta tecnologia de comunicação como material de apoio tanto no conteúdo em EAD, como nas oficinas presenciais. O curso na etapa on-line se iniciou com a apresentação de um vídeo institucional da Web Rádio Água, para que os cursistas conhecessem as propostas do projeto. O vídeo também foi utilizado, no momento da capacitação dos cursistas para o manuseio da plataforma WRA. Também ficaram acessíveis no conteúdo on-line, todos os links que dão acesso aos áudios que são citados, durante o curso, como exemplos de spots. O curso se enquadra nessa área da intervenção, a partir do momento que utiliza as ferramentas audiovisuais com um propósito educativo e como complemento do material pedagógico. Ou seja, agregou-se um produto midiático ao processo de aprendizagem. 


\section{Mediação tecnológica para a educação}

Nessa análise, é importante elucidar que um curso na modalidade EAD se enquadra no campo da Mediação tecnológica para a educação (grifo dos autores). No entanto, é importante pontuar que para ser uma ação educomunicativa, não basta que o curso utilize ferramentas digitais, é preciso ser construído dentro dos princípios da educomunicação (SOARES, 2011).

O curso Elaboração de Spots e Manuseio da Plataforma Web Rádio Água em sua maior parte se faz em uma plataforma digital elaborada com efeitos didáticos, animações e propostas interativas. No entanto, é oportuna uma observação mais criteriosa na formação do ecossistema comunicativo (SOARES, 2000), que são os espaços que sistematizam as ações educomunicativas e dialógicas dos cursistas entre si e com os tutores.

No primeiro momento, reporta-se ao papel do tutor. O profissional que desempenhou a função de tutor/mediador não participou da construção e disponibilização do conteúdo. Ele é contratado por meio de edital para trabalhar por um período de seis meses, como bolsista. Os requisitos obrigatórios e/ou desejáveis para concorrer não incluem conhecimento do campo da educomunicação. O processo seletivo é composto por duas etapas, sendo análise curricular e entrevista por Skype. Após a efetivação do contrato, o tutor passa por um treinamento on-line, quando the é disponibilizado o conteúdo didático do curso. Soares (2002) defende que se o curso é concebido dentro das práticas educomunicativas, os tutores precisam conhecer sobre esse campo de intervenção.

Nessa área de intervenção, como já foi pontuado na subseção Pedagogia da comunicação (grifo dos autores), também são analisados os encontros presenciais. O curso da Web Rádio Água é semipresencial e as aulas acontecem durante um final de semana (sábado e domingo). No entanto, esse momento é marcado pela conclusão do curso, ou seja, o primeiro contato presencial entre mediadores e cursistas não objetivam fortalecer a inter-relação dos participantes, visando a um favorecimento do processo comunicacional no decorrer do curso.

\section{Gestão da comunicação}

Ao analisar essa área de intervenção é importante lembrar que a gestão ficou sob a responsabilidade da equipe da Fundação Parque Tecnológico de Itaipu. Das aulas presenciais participaram também os técnicos da Plataforma Web Rádio Água, com a supervisão da Agência Nacional de Águas. A mediação on-line foi feita pelo tutor, que também participou do encontro presencial.

Como primeiro ponto, remete-se novamente às colocações feitas na área intervencionista Mediação tecnológica para a educação (grifo dos autores), onde se considerou como negativo o fato do tutor não ter participado da elaboração do conteúdo do curso e ter tido contato com a equipe de 
gestores, somente por ferramentas on-line. A contratação dos tutores, como também já foi relatada anteriormente, foi feita para um período de seis meses, com uma carga horária de 20 horas semanais. Não se pontua, nem como quesito desejável, que o candidato tenha conhecimento sobre o campo da educomunicação. Por não ser uma exigência do Edital, seria interessante que após a contratação, houvesse uma capacitado sobre os princípios educomunicativos que norteiam o curso, já que o contato com os cursistas online tinha nos tutores - a única mediação.

No entanto, pelo que atestou esta pesquisa, no curso Elaboração de spots e Manuseio da Plataforma Web Rádio Água, o tutor tinha um trabalho pré-definido, conforme narrado abaixo:

Depois do conteúdo pronto, definíamos o perfil do tutor. Todo processo de entrevista para contratação e treinamento era feito on-line. O compromisso dos tutores era cumprir uma determinada carga horária e no final eles nos encaminhavam um relatório, onde relatavam a presença e o desempenho dos cursistas e algumas observações que eles considerassem necessárias (ENTREVISTADO 4, 2016).

$\mathrm{Na}$ observação-direta do curso, foi possível elencar falhas nos fluxos comunicativos em dois aspectos: na relação cursista e tutor e na interação entre os participantes. O papel do tutor se resumia à cobrança da conclusão das atividades propostas e a motivar o cursista a não abandonar o curso, alertando-o, por e-mail, sobre as atividades a serem completadas. Este formato não coibiu o êxodo dos participantes. Para as 30 vagas disponibilizadas, foram efetuadas 27 inscrições. Do total de inscritos, 13 iniciaram o curso e apenas 8 concluíram, conforme os dados fornecidos pela ANA.

Nas análises documentais e na pesquisa na própria Plataforma Web Rádio Água, foi possível atestar também que não houve mais publicações de spots, após o término do curso. Durante dois não foram postados novos spots pelo CBH-Paranaíba. Em 2014, a Assessoria de Comunicação do Comitê do Rio Paranaíba lançou a campanha de educação ambiental, intitulada 'Minuto

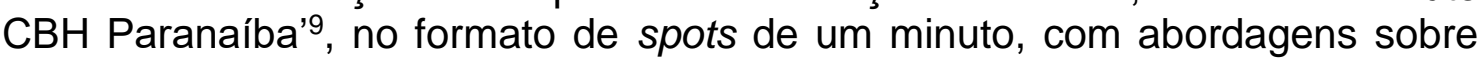
temáticas hídricas, entre elas, a função dos comitês, a lei das águas, o plano de recursos hídricos, o papel da agência das águas e a importância do descarte correto dos resíduos sólidos. A campanha se estendeu até o ano de 2015. Embora os spots tenham sido postados na Plataforma Web Rádio Água, a sua produção não envolveu os gestores que participaram do curso e não

${ }^{9}$ Os spots desta campanha podem ser acessados nos links seguintes: Spot $1-24$ de novembro de 2014 - http://migre.me/w5NJ1 - Spot 2 - 28 de novembro de 2014 http://migre.me/w5NKc - Spot 3 - 5 de dezembro de 2014 - http://migre.me/w5NJA - Spot 4 13 de janeiro de 2015 - http://migre.me/w5NLc .

Revbea, São Paulo, V. 12, № 5: 200-217 2017.

revista brasileira educação ambiental 
seguiu as diretrizes educomunicativas da construção coletiva e participativa. Sobre a não continuidade das ações:

O que inviabilizou a continuidade do processo foi a falta de pessoas para escrever, gravar e editar os spots. O objetivo era que os conselheiros que fizeram 0 curso fossem multiplicadores, mas como a maioria deles, pouco tempo depois. já não pertencia mais ao comitê, esse processo de multiplicação não teve sucesso (ENTREVISTADO 1, 2016).

Após a conclusão do curso, conforme foi apurado durante a pesquisa, não houve monitoramento e nem acompanhamento da equipe promotora para as ações futuras a serem desenvolvidas. O curto período do curso (dois meses) e a falta de acompanhamento após 0 término das atividades comprometeram os resultados a serem alcançados.

Nós trabalhamos o projeto deste curso com recursos de convênios, ou seja, não existem verbas previstas para a etapa de monitoramento e acompanhamento das ações posteriores ao curso. Os recursos alocados são sempre com fins e valores específicos para aplicação do curso e a disponibilização para divulgação dos conteúdos (ENTREVISTADO 3, 2017).

As análises acima relacionam parâmetros que comprometeram o alcance dos resultados propostos. As vulnerabilidades podem ser sistematizadas nos seguintes pontos principais: a) Não ter considerado a importância da familiaridade dos tutores com a proposta educomunicativa do curso; b) Não promover o acompanhamento, monitoramento e fomento dos gestores do projeto junto ao comitê de bacia, após a conclusão do curso; c) Não disponibilização de recursos para ações continuadas; e, d) Alto índice de evasão e falta de clareza no direcionamento de qual seria o papel dos 'comunicadores comunitários' como gestores das próximas ações.

\section{Considerações finais}

De maneira geral, este estudo identificou que as áreas de intervenções educomunicativas embasaram a concepção metodológica do curso Elaboração de Spots e Manuseio da Plataforma Web Rádio Água. No entanto, alguns princípios educomunicativos não foram articulados em sua totalidade, o que comprometeu o objetivo proposto de fortalecer o poder comunicativo do $\mathrm{CBH}$. Nos resultados levantados, percebeu-se que houve falhas na gestão comunicativa e um dos fatores comprometedores foi o fato de se tratar de uma ação pontual, o que vai de encontro com a própria perspectiva da educomunicação, que visa ao estímulo e à formação continuada do cidadão.

Revbea, São Paulo, V. 12, № 5: 200-217, 2017. 
Com os resultados obtidos, foi possível perceber que houve a capacitação para a produção midiática, no caso específico do curso, da elaboração de spots, mas não se problematizou sobre um caminho que garantisse a práxis continuada, considerando que somente a força de vontade e a determinação dos cursistas fossem suficientes para sustentar a continuidade das ações. No formato do curso, não se prevê, após a conclusão do mesmo, a assistência para se encontrar um formato que garantisse a continuidade da elaboração dos spots.

$\mathrm{Na}$ compreensão de que a educomunicação é consolidada de forma intencional, chama-se atenção aqui para o que Soares (2011) aponta como aspectos necessários à construção dos ecossistemas comunicativos: clareza conceitual, planejamento, acompanhamento e avaliação.

Verificou-se também, a partir das entrevistas com os coordenadores e da análise dos relatórios apresentados pelos mesmos, que houve um índice de evasão significativo no curso, o que reflete um dado preocupante, pois além da meta do número de participantes não ter sido atingida, houve um investimento público para essa capacitação. A motivação da evasão não pode ser identificada, já que não foram realizadas entrevistas com os cursistas que desistiram.

No entanto, $\mathrm{n}$ análise geral, respaldada pelo referencial teórico, sugere que o fortalecimento da comunicação dos comitês de bacias hidrográficas, nesse complexo processo de governança das águas, tem na educomunicação uma importante ferramenta, por ser um campo que se fundamenta na mediação, na inclusão, no compartilhamento e na reflexão-crítica. Ao propor a construção coletiva, valorizando a cooperação e a igualdade, as práticas educomunicativas favorecem a gestão participativa, na medida em que desenvolvem a autonomia dos atores envolvidos.

Ao contrário de investir recursos em ações pontuais, é importante trabalhar a educomunicação como programas continuados. As ações isoladas, por mais que se fundamentem nas diretrizes educomunicativas, não são suficientes para fortalecer o poder comunicativo nos comitês e ao mesmo tempo desenvolver as articulações dialógicas entre os atores envolvidos para uma gestão realmente participativa e compartilhada. Por fim, espera-se que os resultados apresentados neste artigo incitem novos formatos de ações educomunicativas para o favorecimento da gestão comunicativa no processo de governança das águas.

\section{Referências}

ALMEIDA, L. Projetos de intervenção em Educomunicação. Campina Grande, $\quad v \quad$ 1.6. 2016. Disponível em: $<$ http://issuu.com/ligiacarvalho77/docs/as reas de interven o da educo 11.> Acessado em 29 de dezembro de 2016. 
BRASIL. Agência Nacional de Águas. Disponível em: http://www2.ana.gov.br/Paginas/default. Acessado em 17 jan 2016.

BRASIL. Lei no 9.433. Institui a Política Nacional de Recursos Hídricos. Diário Oficial da União, Brasília, D.F., 1ํ de setembro de 1997. Seção 1, p.470.

COMITÊ DE BACIA HIDROGRÁFICA DO RIO PARANAÍBA. Disponível em:

http://cbhparanaiba.org.br/ . Acessado em 17 de março de 2015.

FREIRE, P. Pedagogia da autonomia - saberes necessários à prática educativa. 27.ed. São Paulo: Paz e Terra, 2003.

FREIRE, P. A Educação na Cidade. 7ed. São Paulo: Cortez, 2006.

FREIRE, P. Extensão ou Comunicação? 7ª ed. Rio de Janeiro: Paz e Terra, 1987.

FREIRE, P. O Papel da Educação na Humanização. Revista Paz e Terra, Ano IV, № 9, p. 123-132, 1969.

FREIRE, A.M.A. Paulo Freire: Uma História de vida. 1ª Edição Editora Villa das Letras. Indaiatuba, SP. 2006.

JACOBI, P. Participação na gestão ambiental no Brasil: os comitês de bacias hidrográficas e o desafio do fortalecimento de espaços públicos colegiados. In: ALIMONDA, $\mathrm{H}$. Los tormentos de la materia. Aportes para una ecología política latinoamericana. CLACSO, Consejo Latinoamericano de Ciencias Sociales, Buenos Aires. 2006.

KAPLÚN, M. Uma pedagoagia da Comunicação. In: APARICI, R. (Org.). Educomunicação para além do 2.0. São Paulo: Paulinas, p.59-7, 2014.

KAPLÚN, M. La educación para los medios en la formación del comunicador social. En colaboración con María Helena Hermosilla. Montevideo: FCU, 1987.

LIMA, G. Educação pelos meios de comunicação: produção coletiva de comunicação na perspectiva da Educomunicação. 2009. Tese (Doutorado em Educação) - Faculdade de Educação da Universidade de São Paulo, São Paulo, 2009.

MANUAL WEB RÁDIO ÁGUA. Fundação Parque Tecnológico de Itaipu, 2012.

MARCONI, M.; LAKATOS, E.M. Técnicas de pesquisa. 3. Ed. São Paulo: Atlas, 1999.

NÚCLEO DE COMUNICAÇÃO E EDUCAÇÃO da Universidade de São Paulo. Disponível em http://www.usp.br. Acessado em 23 de julho de 2016.

SILVA, J.L. Rádio: oralidade mediatizada: o Spot e os elementos da linguagem radiofônica. São Paulo: Annablume, 1999.

SOARES, I. Educomunicação: o conceito, o profissional, a aplicação Contribuições para a reforma do Ensino Médio. São Paulo: Paulinas, 2011. (Coleção Educomunicação.) 
SOARES, I. Gestão da Comunicação no Espaço Educativo: possibilidades e limites de um novo campo profissional. Apostila Disciplina Educomunicação, Pós Graduação em Comunicação, USP, 2006.

SOARES, I. Metodologias da Educação para Comunicação e Gestão Comunicativa no Brasil e na América Latina. In: BACCEGA, M.A. (Org.) Gestão de Processos Comunicacionais. São Paulo: Atlas, 2002.

SOARES, I. Educomunicação: as perspectivas do reconhecimento de um novo campo de intervenção social. O caso dos Estados Unidos. ECCOS, UNINOVE, São Paulo, v.2 n.2, p.61-80, 2000.

SOARES, I. Mas afinal o que é Educomunicação? NCE: USP. (s.d). Disponível em http://www.usp.br/nce/wcp/arq/textos/27. Acessado em 26 de janeiro de 2016.

SOARES, I. O perfil do educomunicador. NCE: USP. (s.d). Disponível em

http://www.usp.br/nce/wcp/arg/textos/29 . Acessado em outubro de 2016.

SOARES, I. A Educomunicação na América Latina: apontamentos para uma história em construção. In: APARICl, R. (Org.). Educomunicação para além do 2.0. São Paulo: Paulinas, p. 7-27, 2014.

TADDEI, R. Watered-down democratization: modernization versus social participation in water management in Northeast Brazil. Agriculture and Human Values, Vol. 28, 109-121, 2011.

TUNDISI, J.G. Governança da Água. Revista da Universidade Federal de Minas Gerais, n² 2, Vol. 20; p. 222-235, 2013.

WEB RÁDIO ÁGUA. Disponível em: http://www.webradioagua.org/ .Acessado em 14 fev 2015.

YIN R. Estudo de caso: planejamento e métodos. 2a ed. Porto Alegre: Bookman. 2001. 